\title{
First report of konjac mosaic virus in Zantedeschia from Hungary
}

\author{
János Ágoston ${ }^{1,2} \cdot$ Asztéria Almási $^{3} \cdot K^{\text {Katalin Salánki }}{ }^{3}$ - László Palkovics ${ }^{1}$ (i)
}

Received: 18 October 2018 / Accepted: 23 February 2019 / Published online: 15 March 2019

(C) The Author(s) 2019

Keywords Zantedeschia $\cdot$ Konjak mosaic virus $\cdot$ Zantedeschia mosaic virus $\cdot$ Potyvirus $\cdot$ Hungary

In the spring of 2018 a distorted Zantedeschia 'Picasso' plant was observed in Nyársapát, Hungary. The plant was shorter, had narrower, smaller and more acuminate light green leaves with greenish-yellow longitudinal mosaic compared to healthy plants. The spathe did not open; outer color was light green with longitudinal purple stripes. Healthy plants had light purple outer spathe which opened normally. The arrival of warm weather and decreasing rate of plant growth caused masked symptoms, but the leaf margin remained chlorotic. These symptoms indicated/denoted a possible virus infection.

Nicotiana tabacum cv. Xanthi, Nicotiana benthamiana and Chenopodium murale plants were inoculated, during a five week period no symptoms were observed. ACP-ELISA based on MAb PTY1 antibody (Jordan and Hammond 1991) - provided by Agdia - were carried out in duplicate of the leaf sap of Zantedeschia plant. Absorbance values were 1.694 and 1.698, while negative controls were 0.002 and 0.007 , respectively. These results indicated potyvirus infection. To identify the virus, RT-PCR amplification was carried out on the same leaf from which ELISA tests were performed. Universal potyvirus primers, poty7941 and poly $\mathrm{T}_{2}$ were used, as earlier described (Salamon and Palkovics 2005). A single PCR product was cloned into pGEM®-T Easy vector and the nucleotide sequence was determined (GenBank accession No. MH979038), which was $1618 \mathrm{nt}$ long, including the complete coat protein region. The sequence determined included a single $X b a$ I restriction site; $X b a$ I digestion of the original PCR product yielded only the two predicted

László Palkovics

palkovics.laszlo@kertk.szie.hu

1 Department of Plant Pathology, Faculty of Horticultural Science, Szent István University, Ménesi Road 44, Budapest H-1118, Hungary

2 Department of Horticulture, Faculty of Horticulture and Rural Development, John Von Neumann University, Erdei Ferenc Square 1-3, Kecskemét H-6000, Hungary

3 Plant Protection Institute, Centre for Agricultural Research, Hungarian Academy of Sciences, Herman Ottó Street 15, Budapest H-1022, Hungary restriction fragments, indicating the presence of only a single potyvirus in the infected plant tissue. BLAST analysis of the $\mathrm{CP}$ nucleotide sequence revealed highest identity to konjac mosaic virus (KoMV) isolates (synonym zantedeschia mosaic virus) available in GenBank (EU544542, LC114491, LC114492, AB219545) with $96 \%$ to $99 \%$. In Europe, KoMV was previously detected in Germany (Lesemann and Winter 2002) and in the Netherlands (Pham et al. 2002). To our knowledge, this is the first report on the occurrence of KoMV in Hungary.

Acknowledgements Open access funding provided by Szent István University (SZIE). This research was supported by the EFOP 3.6.1-162016-00006 grant and the Higher Education Institutional Excellence Program (1783-3/2018/FEKUTSTRAT) awarded by the Ministry of Human Capacities.

Open Access This article is distributed under the terms of the Creative Commons Attribution 4.0 International License (http:// creativecommons.org/licenses/by/4.0/), which permits unrestricted use, distribution, and reproduction in any medium, provided you give appropriate credit to the original author(s) and the source, provide a link to the Creative Commons license, and indicate if changes were made.

\section{References}

Jordan R, Hammond J (1991) Comparison and differentiation of potyvirus isolates and identification of strain-, virus-, subgroupspecific and potyvirus group-common epitopes using monoclonal antibodies. J Gen Virol 72(1):25-36. https://doi.org/10.1099/00221317-72-1-25

Lesemann D-E, Winter S (2002) Konjac mosaic virus, dasheen mosaic virus and unkown potyviruses infecting Zantedeschia spp. and other cultivated Araceae. Acta Hortic (568):135-141. https://doi.org/10. 17660/ActaHortic.2002.568.19

Pham K, Langeveld SA, Lemmers MEC, Derks AFLM (2002) Detection and identification of potyviruses in Zantedeschia. Acta Hortic (568): 143-148. https://doi.org/10.17660/ActaHortic.2002.568.20

Salamon P, Palkovics L (2005) Occurrence of Colombian datura virus in Brugmansia hybrids, Physalis peruviana L and Solanum muricatum Ait in Hungary. Acta Virol 49(2):117-122

Publisher's note Springer Nature remains neutral with regard to jurisdictional claims in published maps and institutional affiliations. 